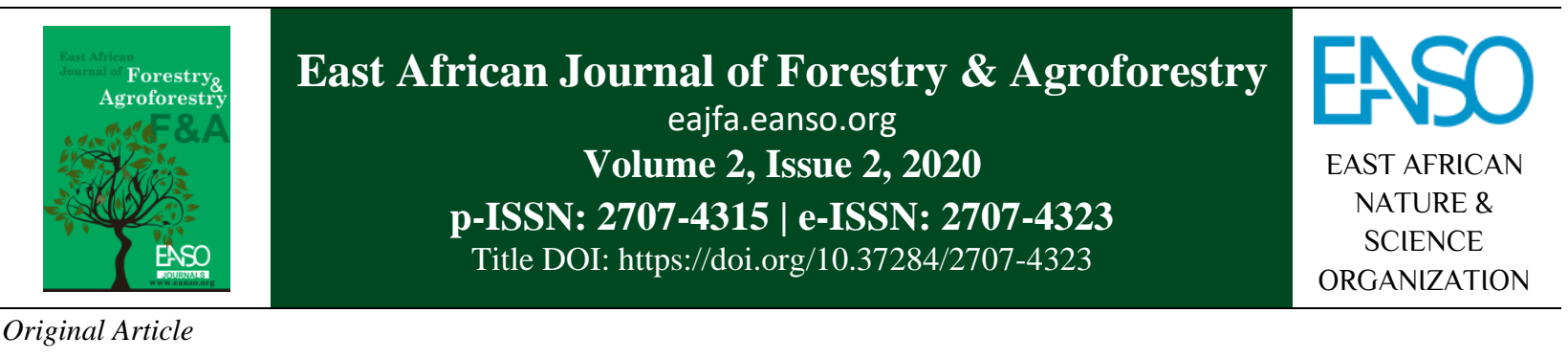

\title{
Tree-Based Conflict Management Mechanism Among Small Landholders in Agroforestry Systems of Kenya
}

\author{
Pauline Bala ${ }^{*}$, Samson Okoth Ojunga ${ }^{2}$, Joyce Okumu ${ }^{3}$, \\ Abdalla Kisiwa ${ }^{4}$, David Langat, $P h D^{5}$ \& Robert Nyambati, $P h D^{6}$ \\ ${ }^{1}$ Kenya Forestry Research Institute, Rift Valley Eco-Region Research Program, Londiani, Kenya \& Kenya School of \\ Government, P. O. Box 23030 - 00604 Lower Kabete, Nairobi, Kenya; ORCID: https://orcid.org/0000-0001-6537-9590 \\ ${ }^{2}$ Kenya Forestry Research Institute, Lake Victoria Basin Eco-Region Research Program, P. O. Box 25199 - 40100, Kisumu, \\ Kenya; ORCID: https://orcid.org/0000-0001-8802-8355 \\ ${ }^{3}$ Kenya Forestry Research Institute, Rift Valley Eco-Region Research Program, P. O. Box 382, Londiani, Kenya; ORCID: \\ https://orcid.org/0000-0003-0013-3877 \\ ${ }^{4}$ Kenya Forestry Research Institute, Rift Valley Eco-Region Research Program, P. O. Box 382, Londiani, Kenya; Email: \\ abdulkyz@yahoo.com; ORCID: https://orcid.org/0000-0002-4730-5210 \\ ${ }^{5}$ Kenya Forestry Research Institute, Rift Valley Eco-Region Research Program, P. O. Box 382, Londiani, Kenya; Email: \\ dkipkirui@yahoo.com ORCID: https://orcid.org/0000-0001-5539-2513 \\ ${ }^{6}$ Kenya Forestry Research Institute-Central Highland Eco-Region Research Program, P.O. Box 20412 - 00200, Nairobi, Kenya. \\ *Author for Correspondence email: paulineballa@gmail.com.
}

Article DOI: https://doi.org/10.37284/eajfa.2.2.214

\section{Article history: ABSTRACT}

15 September 2020

Keywords:

Land Use Conflicts, Competition,

Small Landholding, Agroforestry,

Tree-Based.
Afforestation programs are challenged by competition for land uses. Land use conflicts arise whenever there is divergent use, access and management of the resource or due to incompatible use and inadequate policy. Agroforestry may reconcile competing interests. However, small landholdings remain a challenge due to the negative ecological and economic impacts of most economically preferred trees for agroforestry systems. Such negative impacts lead to the emergence of conflict among different land users and in most instances, slows down afforestation efforts on the farm. This study intended to explore conflicts arising from on-farm tree-planting and other land use practices, to identify the conflict resolution mechanism adopted by land users and to evaluate their strengths and weaknesses in conflict management. Mixed method approach of structured and semi-structured interviews was employed in Bobasi, Kisii County, Kenya. Content analysis, means, frequencies and cross-tabulations were done. Results indicated that small landholdings coupled with poor agroforestry practices were the main source of conflict driven by the ready market for trees of high economic values but with negative ecological impact. Conflict management mechanisms adopted were mainly cooperative methods such as voluntary negotiations between tree farmers and crop owners. These 
included adopting silvicultural control measures, benefit sharing of tree stems along the boundaries and compensation mechanisms for losses incurred by crop owners. Right based management mechanisms were also noted among other land users who believed that what they did with their land and compound was their business and so exhibited competitive approaches such as avoidance, coercion, and adjudication.

\section{APA CITATION}

Bala, P., Ojunga, S., Okumu, J., Kisiwa, A., Langat, D., \& Nyambati, R. (2020). Tree-Based Conflict Management Mechanism Among Small Landholders in Agroforestry Systems of Kenya. East African Journal of Forestry and Agroforestry, 2(2), 24-39. https://doi.org/10.37284/eajfa.2.2.214

\section{CHICAGO CITATION}

Bala, Pauline, Samson Ojunga, Joyce Okumu, Abdalla Kisiwa, David Langat, and Robert Nyambati. 2020. "Tree-Based Conflict Management Mechanism Among Small Landholders in Agroforestry Systems of Kenya”. East African Journal of Forestry and Agroforestry 2 (2), 24-39. https://doi.org/10.37284/eajfa.2.2.214.

\section{HARVARD CITATION}

Bala, P., Ojunga, S., Okumu, J., Kisiwa, A., Langat, D. and Nyambati, R. (2020) “Tree-Based Conflict Management Mechanism Among Small Landholders in Agroforestry Systems of Kenya”, East African Journal of Forestry and Agroforestry, 2(2), pp. 24-39. doi: 10.37284/eajfa.2.2.214.

\section{IEEE CITATION}

P. Bala, S. Ojunga, J. Okumu, A. Kisiwa, D. Langat, and R. Nyambati, "Tree-Based Conflict Management Mechanism Among Small Landholders in Agroforestry Systems of Kenya”, EAJFA, vol. 2, no. 2, pp. 24-39, Sep. 2020.

\section{MLA CITATION}

Bala, Pauline, Samson Ojunga, Joyce Okumu, Abdalla Kisiwa, David Langat, and Robert Nyambati. "Tree-Based Conflict Management Mechanism Among Small Landholders in Agroforestry Systems of Kenya". East African Journal of Forestry and Agroforestry, Vol. 2, no. 2, Sept. 2020, pp. 24-39, doi:10.37284/eajfa.2.2.214.

\section{INTRODUCTION}

Management of natural resources for the production of goods and the provision of ecosystem services such as conservation of biodiversity, water, and even air has led to competition for land among different user groups. Land use conflicts or natural resource conflicts arise when there are divergent views on land use policies causing negative impacts on other land users or whenever an introduced management system contradicts the pre-existing local management systems and the new system is incompatible to the pre-existing land uses (Kazoora, 2003). These conflicts also arise from misunderstandings and lack of information about policy when there are contradictions and lack of clarity in laws and policies; inequities in the distribution of resources, or poor policy and programme implementations, as well as historical relationships and power differences among actors.
Depending on underlying issues and how they are addressed, conflicts may yield different impacts. They may be violent or non-violent and, in some instances, lead to loss of property or livelihood strategy. Under the common property regime in natural resource management, a number of conflicts have been reported which include conflicts related to the utilization of natural resources which arise due to divergent interests of forest user groups where in some instances, consumptive users do not consider the interests of other users such as nonconsumptive users (Gombya-Ssembajjwe, 1998). Conflicts also arise due to access/lack of access to natural resources, or due to decision making in the management of natural resources (GombyaSsembajjwe, 1998). An effort to reconcile competing land uses between forestry or conservation with other competing land use practices such as agriculture led to the development of agroforestry as a useful land use practice to reconcile agriculture, livestock production, forest conservation, soil and water conservation and 
mitigation of climate change in small landholdings (Sobola, Amadi, \& Jamala, 2015).

In Kenya, farm forestry has been promoted under the Agriculture (Farm forestry) rules 2009 to enhance forest cover within the agricultural landscape of Kenya. The rules require that $10 \%$ of each individual's agricultural land in rural areas be covered by trees (GoK, 2009a). Farm forestry is defined as managing of trees on farms whether singly, in rows, lines, boundaries or woodlots or private forests (GoK, 2009a). However, conflicts arising from competing land uses on farms hinder adoption of agroforestry practices and adherence to the farm forestry rules, especially among small landholding farmers (Tengnas, 1994).

Conflicts between two or more land users adjacent to each other are common in agroforestry systems due to the following reasons: negative tree-crop interaction leading to loss of the productivity of crops adjacent to the tree woodlots or to the boundary of planted trees in agroforestry systems/ farm forestry. Similarly, boundary or woodlot planting and lack of information on proper management of boundary plantations of certain tree species lead to conflicts between neighbours or different user groups of land such as owners of shallow wells (Joshi \& Palanisami, 2011; Kenya Forest Service, 2009). Some of the most preferred species for planting in the agroforestry systems/on farms are those that also have high economic value but at the same time pose a great threat to the productivity of other crops planted in the adjacent lands. An example includes Grevillea robusta mostly preferred in tea plantations in Muranga, Kisii, Kericho and Vihiga counties and has been reported to host pests and diseases that do affect other crops as well (Mugunga, 2016). Adoption of Eucalyptus spp. for on-farm planting has been on the rise since the introduction of fast-growing Eucalyptus varieties and species in Kenya such as Eucalyptus grandis, among other fast-growing varieties (Mugunga, 2016). However, the destruction caused by various tree species on agricultural crops, among other properties has also been reported. This happens where approved silvicultural practices are not applied and improper land use practices such as the poor spatial arrangement of trees on the farm are done.
Depending on the level of conflict management and dispute resolution, competing land uses and land conflicts may lead to loss of livelihood strategy, human displacement, violence and even casualties in others instances. In other instances, response to conflicts may be constructive rather than destructive and lead to a win-win situation after reframing the conflicts to convert a competition over the resource to cooperation (Gerber, 2011).

The constitution of Kenya 2010 provides for the use of alternative and traditional dispute resolution mechanisms before resorting to court in managing natural resource conflicts (Gerber, 2011). However, there lacks clear policies on how conflicts arising from competing land uses between forestry and agriculture may be resolved, especially where landholdings are very small. General literature on conflict management and resolution mechanisms at the local level has pointed to negotiations, mediation, conciliation and arbitration (Nader \& Todd, 1978; Pendzich, Thomas, \& Wohlgenant, 1994). However, the mechanism used by local community members to manage conflicts arising from farm forestry level has not been documented. Similarly, it is important to establish whether such mechanisms are usually effective in reducing conflicts between the involved user parties. It is against this backdrop that this study intends to evaluate the local conflict management mechanisms among small landholders practising farm forestry.

\section{Study Objective}

The specific objectives of the study included:

(a) To understand conflicts arising from tree planting among small landholdings.

(b) To determine the conflict management mechanisms between neighbouring small landholders in Kisii County.

(c) To determine the effectiveness of the various mechanisms used to resolve conflicts arising from boundary tree planting 


\section{LITERATURE REVIEW}

Analysis of conflicts is necessary to have a clear and deep understanding of the special characteristics of the particular conflict, the causes of the conflict and the actors involved (including their positions, attitudes, behaviour, interests, needs and motivations) as well as their relations with each other. Conflict and dispute are two terms that are often used interchangeable, yet their meaning slightly varies. Conflicts characterize all human societies and are inevitable, whereas disputes are more focused and articulated to the expression of differences over particular resources, needs and interests or goals (Loode, Nolan, Brown, \& Clements, 2009). Conflicts often involve at least two parties who disagree over the distribution of material and symbolic resources or perceive their underlying cultural values and beliefs to be different (Loode, Nolan, Brown, \& Clements, 2009). Conflict may also originate from the social and political make and structure of the society (Reimann, 2004). Conflicts are generally considered as incompatible activities where the actions of one person interfere or may obstruct the action of another party (Morton, 1973). These incompatible actions may occur in both competitive and cooperative context.

Conflicts related to conservation have been defined as situations when more parties who hold strong opinions clash over their objectives or interests where one party is perceived to assert his interest at the expense of another/other parties. Therefore, this conflict related to competing interest is between humans (Redpath et al., 2013). Redpath et al. (2013) also report that land use conflicts (Conservation conflicts) emerge when the position of parties representing one land use such as conservation is threatened by the position of those holding different world views such as that of cash crops farmers have a different world view from other land users such as tree farmers, fisheries, water distributors, settlers or when one party is excluded by another in the decision-making process by other land users by imposing their interests on the rest of other parties. In this study, we focus on conflicts that arise from competing land uses with trees growing on farms.
Understanding conflicts in land use such as conservation conflicts should employ multidisciplinary understandings from social science, natural science and humanities since it arises from deeper cognitive levels and may be linked to power relations, changing attitudes and values that are rooted in social and cultural history (Redpath et al., 2013). The broad non-exclusive categories of conflicts include variation in understandings between stakeholders on the land use practices engaged in. For instance, poor understanding of human-wildlife relations, lack of inclusion of some stakeholders in planning, the existence of disadvantaged stakeholders in negotiations or when the land use practice based on historical experience appear threatening (Redpath et al., 2013).

Conflicts have been described as dynamic, constantly changing and interactive. Different authors have suggested different stages and ways of characterizing conflict escalation. For instance, Glasl, 1982 suggests nine steps, Noll, (2000) suggests five phases and Brahm (2003) suggests eight phases. Other scholars such Pondy (1967) have categorized the conflict stages as follows: the latent stage where the participants are not aware of the conflict presence between them; the perceived stage where parties are aware of the existence of the conflicts, felt stage where anxiety and stress sets in between the parties, confrontations come in and is marked with occasional fighting or other levels of violence and each party looks for resources and supporters; the manifest stage where the conflict is open and can be observed and is characterized with violence, it is a crisis, and at its peak when the tension and the violence are intense. Conflict can easily get out of control. There is rarely any communication between the parties, who are fighting with and publicly accusing each other. In the worst case, the different sides are at war. The aftermath stage or outcome stage follows when conflict resolution or dissolution occurs (Pondy, 1967) In any case, tension and violence decrease but the conflict is not yet settled. Post-conflict: at this stage, relations have become more normal again. However, if the roots of the conflict have not been adequately addressed and if the incompatible goals still prevail, the chances are that the situation will turn again into a pre-conflict. When analyzing conflict, identification of the current stage of the 
conflict is important for devising appropriate manner of intervention or dispute.

How parties respond to conflict or manage conflicts may be classified broadly as interest-based which includes strategies such as negotiations and mediation; right-based which includes litigations or power-based exemplified by the use of force threats and violence (Boulle, 2005; Condliffe, 2002; Ury, Brett, \& Goldberg, 1993).

Dispute resolution continuum range from practices in which parties retain full control of the process to those in which the third parties are involved with some degree of control (Hassall, 2005). The extent of formal participation in the dispute process by state agencies is believed to vary according to traditions, culture and needs (Hassall, 2005). The resolution continuum includes the following mechanisms: negotiations which are always deemed to offer the best option and opportunity for peaceful resolution mechanism. It is a voluntary agreement between both parties. It is often preferred as it is believed to deepen relationships and strengthen community at the local and global scale if well done and managed. In negotiations, involved parties engage in talks to resolve or manage conflict without any external parties getting involved in the dispute or conflict management process. It, therefore, remains a confidential process between the conflicting parties.

Mediation resolution mechanism is the second in the continuum and is also a confidential problemsolving process where a third party without any ability to impose settlement assists the participants to reach a negotiated settlement of their differences. It usually serves to satisfy the needs of the disputing partners. It also helps preserve or strengthen the future relationships between involved parties. A mediator sits down with the two partners and guides their discussion. The mediator is a neutral third party, with no independent authority or ability to impose a settlement - his or her role is not to make the final decision, but to guide the partners to a mutually-agreed-upon solution. This method works best when partners wish to retain control over the outcome of the conflict resolution process.

Arbitration is the third mechanism in the continuum, where a neutral and mutually agreeable third party is involved. However, the disputing parties have the opportunity to argue their side of the dispute during arbitration rather than working together to come to a solution that applies in mediation. The arbitrator then renders a final position which should be a binding decision to the solution to the dispute unless the disputing parties have agreed beforehand. Like mediation and negotiations, confidentiality is achieved while the dispute resolution mechanism is ongoing not in a public forum or courtroom. Compared to litigations, the social relationship can be preserved and the dispute can be resolved privately based on terms that both partners agree upon. Therefore, there is an option to make mutual benefit agreements to create the best solutions for both partners. If using alternate dispute mechanisms above fails, then partners can proceed to litigations. Litigation or adjudication is usually considered by most as the last resort to conflict resolution because it usually turns the conflict into a situation where the final outcome is a win-loss one and pursuing legal action can be a drain on time and resources.

Both litigation and arbitrations if conducted in a clear and fair arbitration manner provide institutional safeguards that provide accountability, thereby making the environment predictable and credible. The institutions help to establish a high level of trust and cooperation between the parties. When clear procedures in arbitration and independent courts exists, the certainty is increased for both disputing parties. However, the quality of such institutions is critical in signalling the government's commitment to constraining the discretionary power of the regulators.

Other mechanisms used outside the continuum include avoidance where one party acts in a way to keep a conflict from becoming acknowledged publicly. Coercion is also adopted in some instances where either party use a forceful action to enforce once will.

All these mechanisms may be classified broadly as either competitive or cooperative depending on whether it is a win-lose scenario or win-win situation is achieved (Morton, 1973). When parties have cooperative goals, as one of them moves toward attaining goals, the other party also get to achieve their goals too. Conversely, in competitive goals, there is a negative relation between the 
parties' goals; thus, only one party succeeds (Tjosvold, Wong, \& Chen, 2014).

The effectiveness of conflict resolution mechanism is measured by its resolution in private, resolution that cause minimal disruption in service to the enduser and in a manner that opens channels of communication and reduces the potential for disputes thereafter/ recurrence of disputes in the life of the involved parties.

The effects of each conflict resolution mechanism may be described in terms of cost incurred in conflict resolution or the opportunity cost forgone when certain mechanisms are opted for. It is believed that interest-based processes are more time and cost-efficient, provide more satisfaction to the disputing parties, are less destructive for the relationship of the parties than processes. For instance, adversarial litigation often results in more durable solutions to which disputants stay committed, therefore lessening the possibility of appeal, future conflict or dishonouring of the agreement (Ury, Brett, \& Goldberg, 1993).

The regular occurrence of disputes over certain areas /places can be a symptom of a much deeper conflict in which individuals or groups are embroiled. There may be two levels of intervention processes; one, interventions aiming at resolving or settling the particular dispute (for example through adjudication or mediation of the claims of two different families over a particular garden). Secondly, intervention processes that aim at addressing the often much larger underlying conflict (for example dialogue processes which involve the whole community or even a number of communities and which aim at airing grievances and inequalities which are perceived by different groups in the area). Third, restorative processes attempt to heal the damage that was caused by the conflicting parties.

\section{Empirical and Technical Recommendations on Tree Boundary Planting Conflicts Resolution Mechanisms}

Technical specification on reducing conflicts arising from boundary tree planting had been suggested by Tengnas (1994) where it is recommended that boundary tree planting requires prior agreement between the neighbouring landowners to avoid conflicts caused by the destruction of trees to various properties and farms. Alternatively, the sharing of trees planted on the boundaries may also reduce such conflicts. For instance, two rows of trees may be planted and the neighbours share the one row on each side of the boundary then each farmer grows and manages his own trees. This may occupy more land than a single line/ row. Alternatively, ownership may be shared at predetermined intervals of trees, like every second tree planted on a single line to be shared with the other party. This required keeping proper track and record of the tree ownership. If the species are different, one species may outcompete the other and so one farmer may be disadvantaged. Alternatively, ownership may be shared from different sections of the boundary and choose trees species according to the farmers' preferences.

Earlier in a study conducted in Kenya, Dewees (1995) reports of tree planting on-farm and boundary planting practice for demarcation onfarm and how specific tree species were preferred for boundary planting. To avoid conflicts between neighbours or landowners, big trees such as Ficus tree species were planted to mark the boundary in Kikuyu rural. The regeneration of these Ficus species would be managed so that only one big tree would be allowed to grow to maturity. Also pruning and pollarding of trees planted on the boundaries was common and that the trees planted along the boundary ought to be multipurpose such as the provision of medicinal values, fruits, among other benefits such as fodder (Dewees, 1995). Similarly, proper site species matching on the boundaries was highly promoted. For instance, tree species with a medium lifespan such as Cordia abyssinica and Croton megalocarpus were preferred for planting on the boundaries compared to those with shorter lifespan like Sesbania sesban and Acrocarpus fraxinifolius which have to be combined with more permanent tree species. Competitive tree species such as Eucalyptus spp., Acacia mearnsii and pine were less advisable for planting in the boundaries. Non-commercial fruit trees like Syzygium cuminii, Vitex spp. and Annona spp., have been suggested to be suitable for boundary planting (Dewees, 1995; Tengnas, 1994).

In Florida where conflicts arose between tree urban tree growers and the urban infrastructural 
developers were bigger trees led to the destruction of such infrastructural facilities as the sewer lines, water supply lines, sidewalks, streets, parking lots and swimming pools, bigger trees would be replaced by younger ones, but this proved unsustainable and costly (Costello, McPherson, Burger, \& Dodge, 2000). Thus, preventative measures were devised and recommended to avoid infrastructure- tree growing conflicts in the urban landscapes of Florida. This was done through proper planning long before the trees are grown to avoid much cost and damage to both infrastructure and trees. Through such planning, site requirements for long-term growth and vigour of trees are made an integral part of the original plans for the urban streetscape. Also, species selection was considered an important element in the strategy to reduce infrastructure and tree damage conflicts Costello, McPherson, Burger, \& Dodge, 2000). The selection should be in such a manner to allow for specific tree species' ability to thrive in a specific site with its limited space and altered soil conditions (Nicoll \& Coutts, 1997).

A study by Gerber (2011) on conflicts over industrial tree plantations such as palm oil, rubber and wood in the south shows the existing conflict between the companies and local population due to the impacts of plantation caused by the resistance from the corporates control over land leading to displacement and end of local and uses. The conflicts also get managed through dialogue and direct confrontation. Certain competing goals may be achieved, such as demonstration, lawsuit, roadblock protesting, uprooting of trees. Most of the responses from the authorities are repressive

\section{METHODOLOGY}

\section{Study Area}

The study was carried out in Kisii County, which is characterized by very small landholdings, ranging from $0.2 \mathrm{Ha}$ to $2.1 \mathrm{Ha}$ (0.5 acres-5.18 acres) of land and high adoption of on-farm tree planting (Kisii County Government, 2018-2022). The small landholdings are as a result of high population pressure on land, which results in subdivisions and fragmentation of holdings. Kisii County shares common borders with Nyamira County to the North East, Narok County to the South and Homabay and
Migori Counties to the West. The County lies between latitude $0030^{\prime}$ and $10^{\circ}$ South and longitude $34^{0} 38^{\prime}$ and $35^{\circ}$ East. It covers an area of $1,302 \mathrm{~km}^{2}$, a population of $1,266,860$ people as per the 2019 census. Politically, the County is organized into 9 constituencies namely, Bobasi, Bonchari, Bomachoge Chache, Bomachoge Borabu, Kitutu Chache North, Kitutu Chache South, Nyaribari Chache, Nyaribari Masaba, and South Mugirango. The most notable features in the County include hills such as Sameta (1970 m), Nyamasibi (2,170 $\mathrm{m})$, Kiong'anyo (1,710 m), Kiamwasi (1,785 m), Kiongongi, Kiombeta, Sombogo, Nyanchwa and Kegochi hills which experience frequent landslides and thus tree planting is an appreciated activity in the midst of intensive farming The general slope of the land is from East to West (Kisii County Integrate Development Plan 2018-2022)

\section{Study Design and Data analysis}

The survey design which entailed describing, recording, analyzing and reporting of the current status of tree-based conflicts on-farm was used. Households were selected using snowball sampling method where farming households which had treebased conflicts were selected and research tools administered to them. A total of 236 respondents were sampled from two locations of Kinyerere and Rise from Bobasi Sub-County, which had a high incidence of tree-based conflict. Semi-structured questionnaires were used to obtain both qualitative and quantitative data from households selected. The Focus group discussions were done consisting of women, youths, village elders and other key stakeholders in agroforestry from the two locations sampled for qualitative discussion on tree-based conflicts. Information was also collected from 30 key informants drawn from local administration, judiciary officials, County Government officers and community leaders which was regulated from the Focus Group Discussion findings. The data collected were coded, and entry is done using Microsoft Excel office. The data collected were coded, entered and cleaned for consistency and quality checks in Microsoft Excel office then later imported into and analyzed using Statistical Package for Social Sciences (SPSS). 


\section{RESULTS AND DISCUSSION}

\section{Characteristics of the respondents}

The majority of respondents interviewed 64\% (151) were male, while $36 \%$ (85) were female, with a total mean age of 49 years. Those who had attained secondary education level were $42 \%(99)$, primary $32 \%$ (76), 16\% (38) had tertiary education level and none $10 \%$ (23). The land size holdings per household stand at 0.75 acres per household with mean land for agricultural production at 0.97 acres, woodlots (0.62 acres), fodder crop (0.41 acres) and fruit orchards (0.40 acres).

\section{Nature of Tree-Based Conflicts and its Manifestation or Effects}

The result shows that majority of the respondents indicated that conflicts arose from tree-crop conflict accounted for $65.2 \%$ of all tree on boundary conflicts. This is where trees affect the productivity of crops such as tea and maize by competing for nutrients, allelopathy, yet the crop farming forms the main agricultural practice of most households. The rest of the negative effects caused by trees that lead to conflict included house destruction, land encroachment, health risk when trees are casting shadows on the properties, littering neighbours' compounds and causing the death of livestock when harvesting happens. This means conflicts arose between tree growers and crop farmers, tree growers and land or property owners and tree growers and livestock keepers.

Table 1: Classification of conflicts according to the effects on different land users

\begin{tabular}{ll}
\hline Classification of Conflict & Percentage (\%) \\
\hline Tree-crops conflicts & 65.8 \\
Trees-house destruction & 13.9 \\
Tree- land encroachments & 6.5 \\
Tree and health Risk & 4.6 \\
Tree-Littering compound & 2.8 \\
Tree ownership conflicts & 2.8 \\
Tree-and water drainage on rivers & 1.9 \\
Tree- Livestock death & 1.9 \\
\hline
\end{tabular}

The farming households had conflict escalated into stages of assaults $(54.2 \%)$, mild stage $(33.6 \%)$ and $12.2 \%$ had escalated into violence stage which often was characterised by the killing of parties due to property rows. The tree-crop conflicts accounted for $60.2 \%$ of all tree conflicts. Most of the conflicts are at the latent stage $(50 \%)$ while felt stage accounted for $41.7 \%$. These conflicts are manifested through disagreement between neighbouring families after parties express their dissatisfaction with their neighbours, assault of one party, felling of trees by farmers without the owner's consent and in severe instances of violence. The felt stage $(41.7 \%)$ is the second most common stage of conflict-related to tree planting. At this stage, the conflict is perceived, recognized, and the negative effects of the cause felt by at least one party but may not lead to any tension. This is manifested mainly by the agreed party having expressed their dissatisfaction to their neighbours. $4.2 \%$ of the conflicts are at advances stages of manifest where two parties engage in behaviours which evokes a response from each other. The most obvious of these responses are open aggression, apathy, sabotage, withdrawal and perfect obedience to rules. Cases of violence, assault and serious disagreement including the killing of parties. especially widowed women have been recorded in Kisii.

\section{The Extent of the Tree-Based Conflicts}

To show the severity of the conflicts and how the conflicts are manifested by the parties involved, the extent and the stage of the conflicts classes above were scored. Most conflicts were at the latent stage (50\%) where the conflict is subtly expressed, but parties are not aware of the existence of the 
conflicts between them, followed by the felt stage $(41.7 \%)$, where anxiety and stress sets in between the parties, it is characterized by confrontations and is marked with occasional fighting or other levels of violence and each party looks for resources and supporters. Other few interviewees had experienced conflict at the advanced level of manifest and perceived stages at $0.9 \%$ each. At the perceived stage, participants parties are aware of the existence of the conflicts, whereas, at the manifest stage, conflict is open and can be characterized by violence and a crisis, and at its peak. There is rarely any communication between the parties, who are fighting and publicly accusing each other.

Figure 1: Stages of tree-based conflicts on farm

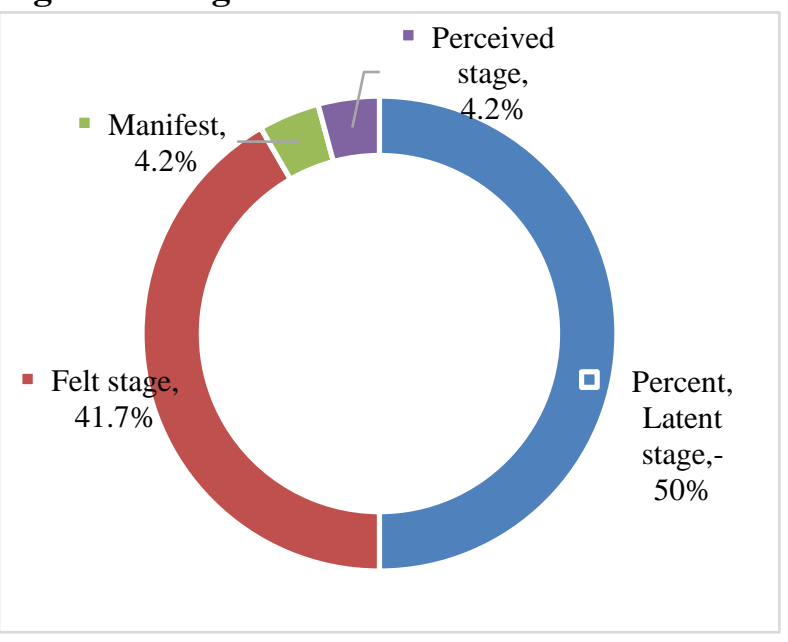

The manifestation of tree-based conflicts

Results indicate that all the recorded tree-based conflicts had been manifested mainly through assault $(54.2 \%)$ where the parties had confronted each other and at least exchanged verbal altercations followed by mild manifestations $(33.6 \%)$ and a few violence (12.2\%). Even though violence cases were few, it was severe because in other instances it would be accompanied by the killing of parties involved and especially widowed women when the tree planting is intertwined with the contestation of land ownership

Table 2: Manifestation of tree-based conflicts

\begin{tabular}{ll}
\hline Extent of conflict & Percent (n) \\
\hline Assault & $54.2(128)$ \\
Mild & $33.6(79)$ \\
Violence & $12.2(29)$ \\
Total & $\mathbf{1 0 0}(\mathbf{2 3 6})$ \\
\hline
\end{tabular}

The manifestation of conflict in relation to different conflict classes

Classes of Tree-based conflicts nave been expressed in different ways. whereas conflicts arising from negative effects of trees on crops were expressed in all three manners including an assault, mild and even violence this was the case for conflicts arising from contestation of tree ownership and house destruction by trees. The tree crops conflicts in mild conflict stage accounted for $40.6 \%$ and higher under assault state $(51.6 \%)$ while tree house destruction conflicts are majorly in assault state $(71.4 \%)$ The few cases of tree and health risk related conflicts were all expressed through violence (see Table 3).

Table 3: Manifestation of conflict in relation to different conflict classes

\begin{tabular}{llll}
\hline Conflict classification & \multicolumn{3}{l}{ Extent of conflict per type (\%) } \\
& Assault & Mild & Violence \\
\hline Tree and health Risk & 0 & 0 & 100 \\
Tree crops conflicts & 51.6 & 40.6 & 7.8 \\
Tree land encroachments & 33.3 & 66.7 & 0 \\
Tree livestock death & 50 & 0 & 50 \\
Tree ownership & 33. & 33.3 & 33.3 \\
Tree shade conflict & 100 & 0 & 0 \\
Tree-Littering compound & 33.3 & 66.7 & 0 \\
Trees house destruction & 71.4 & 21.4 & 7.1 \\
\hline
\end{tabular}




\section{Damages and Losses Introduced by Tree Planting in the Boundaries Leading to Conflicts}

The most prevalent loss as a result of conflicts are crop losses (36.9\%), houses destruction (22.1\%) and decline in soil fertility loss (13.9\%) and affecting water sources $(9.8 \%)$

Figure 2: Damages and losses introduced by tree planting in the boundaries leading to conflicts

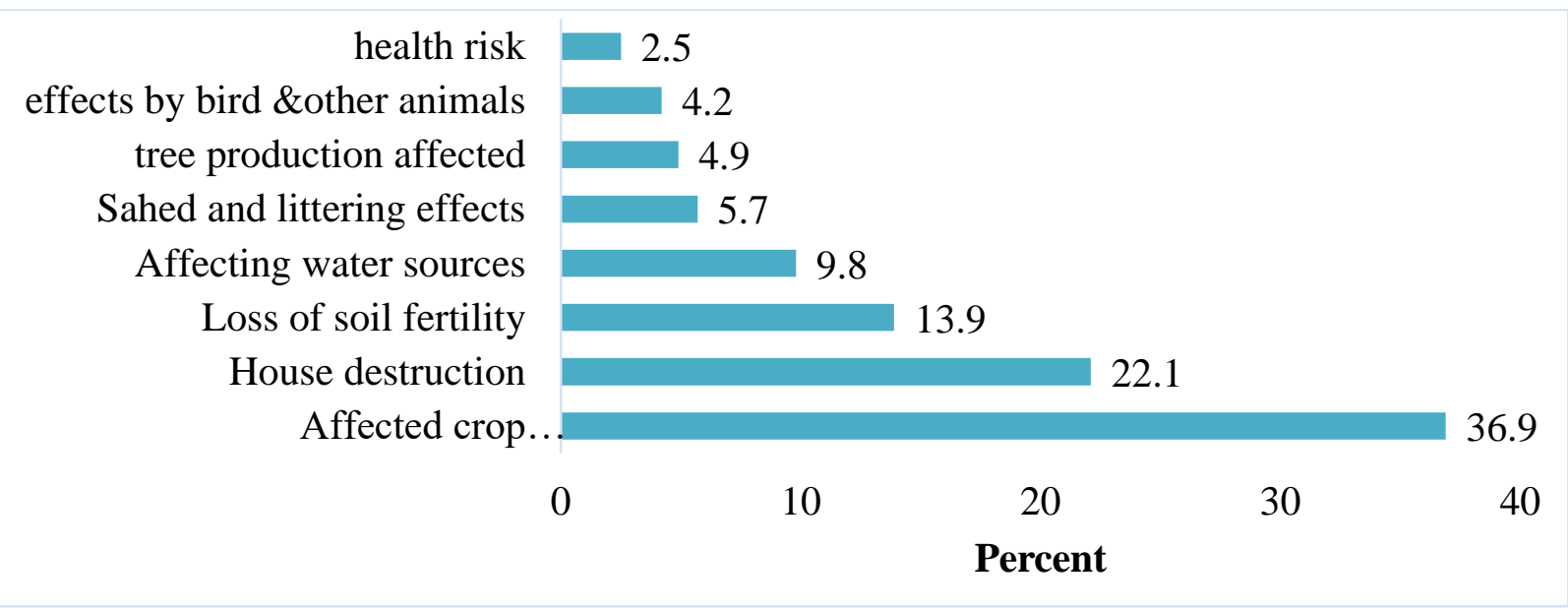

Relationship between Tree Species and Nature of Conflicts

The trees planted on the boundary includes Eucalyptus spp., Croton macrostachyus, Grevillea robusta, Markhamia lutea and Psidium guajava. There is an association between tree species planted and the nature of conflicts observed under boundary planting. Eucalyptus and Grevillea caused the most cases of tree ownership conflicts $(85.7 \%)$ and $(14.3 \%)$ respectively when the ownership of trees is contested. They were also associated with most cases of tree and health risks at $80 \%$ and $20 \%$ respectively when the trees caused physical injuries to persons, overcast shade and causing respiratory diseases. Most Eucalyptus species contributes to $50.7 \%$ and Grevillea robusta $38.4 \%$ of all tree cropbased conflicts, but Grevillea robusta contributed to the highest cases of tree and land encroachment conflicts. All trees listed for planting I farm were associated with varying level to leading to negative interactions with the crop.

Table 4: Relationship between trees and nature of conflicts on boundary tree planting

\begin{tabular}{llllll}
\hline Nature of conflict & \multicolumn{4}{l}{ Tree Species planted on Boundaries } \\
& $\begin{array}{l}\text { Croton } \\
\text { macrostachyus }\end{array}$ & $\begin{array}{l}\text { Eucalyptus } \\
\text { species }\end{array}$ & $\begin{array}{l}\text { Grevillea } \\
\text { robusta }\end{array}$ & $\begin{array}{l}\text { Markhamia } \\
\text { lutea }\end{array}$ & $\begin{array}{l}\text { Psidium } \\
\text { Guajava }\end{array}$ \\
\hline Trees house destruction & $4.8 \%$ & $57.1 \%$ & $38.1 \%$ & $0 \%$ & $0 \%$ \\
Tree ownership & $0 \%$ & $85.7 \%$ & $14.3 \%$ & $0 \%$ & $0 \%$ \\
Tree land encroachments & $0 \%$ & $25.0 \%$ & $75.0 \%$ & $0 \%$ & $0 \%$ \\
Tree crops conflicts & $4.1 \%$ & $50.7 \%$ & $38.4 \%$ & $5.5 \%$ & $1.4 \%$ \\
Tree and health Risk & $0 \%$ & $80.0 \%$ & $20.0 \%$ & $0 \%$ & $0 \%$ \\
\hline
\end{tabular}

\section{Relationship between Land Sizes and Nature of Tree-Based Conflicts}

There is a significant relationship between the land size and the nature of tree-based conflicts encountered by land users. Smaller land sizes ranging between 0.5 to 3 acres at $67.5 \%$ and 3-5 acres at $32.5 \%$. There were more respondents encountering land encroachments with smaller landholding than there are with bigger landholdings $(12.5 \%)$ followed by more farmers with tree-crop conflicts due to small landholdings compared to 
bigger holdings. The conflicts arising from littering compounds was experienced equally in large and small landholdings and so was the case of conflicts arising from livestock deaths caused by trees(Table $5)$.

Table 5: Tree-based conflict per Land size configuration

\begin{tabular}{lll}
\hline Nature of conflict & \multicolumn{2}{l}{ Land size categories $(\boldsymbol{\%})$} \\
\cline { 2 - 3 } & $\mathbf{0 . 2 5 - 3}$ acres & $\mathbf{3 - 5}$ acres \\
\hline Tree crop conflict & 72.6 & 27.4 \\
Tree land encroachments & 87.5 & 12.5 \\
Trees house destruction & 70.0 & 30.0 \\
Tree and health Risk & 56.3 & 43.8 \\
Tree-Littering compound & 50.0 & 50.0 \\
Tree shade conflict & 0 & 100.0 \\
Tree ownership & 42.9 & 57.1 \\
Tree livestock death & 50.0 & 50.0 \\
Total & 67.5 & 32.5 \\
\hline
\end{tabular}

Tree-based Conflict Copping/Handling Mechanisms

There were more cooperative mechanisms of dealing with tree-based conflicts by respondents than non-cooperative or competing mechanisms at $58.3 \%$ and $41.6 \%$ respectively. Among the cooperative mechanisms, tree felling featured as the most prominent coping mechanism (31.3\%).

Table 6: Tree-based conflict handling mechanism categorized as competing or cooperative

\begin{tabular}{|c|c|c|c|c|}
\hline $\begin{array}{l}\text { Classification } \\
\text { of mechanisms }\end{array}$ & Competing mechanisms & Nature of conflict & $\begin{array}{l}\text { Percentage } \\
(\%)\end{array}$ & $\begin{array}{l}\text { Total } \\
\text { percentage }\end{array}$ \\
\hline \multirow[t]{6}{*}{ Competing } & Defy orders from an Authority & $\begin{array}{l}\text { Tree and health risk, } \\
\text { Tree land } \\
\text { encroachments }\end{array}$ & 14.6 & $41.6 \%$ \\
\hline & Ignoring engagement & & 12.5 & \\
\hline & Defy agreements & & 6.3 & \\
\hline & Planting similar species & & 3.1 & \\
\hline & No action & & 3.1 & \\
\hline & $\begin{array}{l}\text { Unresolved pending issue at the } \\
\text { chief's office }\end{array}$ & & 1.0 & \\
\hline \multirow[t]{8}{*}{ Co-operative } & Tree Felling & $\begin{array}{l}\text { Tree and health risk, } \\
\text { Tree crop conflicts }\end{array}$ & $31.3 \%$ & $58.3 \%$ \\
\hline & Silvicultural management & & $8.3 \%$ & \\
\hline & $\begin{array}{l}\text { Agreements to short term } \\
\text { planting }\end{array}$ & Tree crop conflicts & 2.1 & \\
\hline & Change tree planting site & Tree crop conflicts & 1.0 & \\
\hline & $\begin{array}{l}\text { Dig trenches to avoid root } \\
\text { extension }\end{array}$ & Tree crop conflicts & 1.0 & \\
\hline & Sharing tree ownership & Tree crop conflicts & 1.0 & \\
\hline & Monetary compensation & $\begin{array}{l}\text { Tree causing } \\
\text { livestock deaths }\end{array}$ & 6.3 & \\
\hline & Proper site species Matching & & 4.2 & \\
\hline
\end{tabular}


Conflict Management Process through ThirdParty Institutions interventions

These institutions used various mechanisms for solving and mitigation of conflicts with negotiations (44.2\%) being the most preferred through the engagement of conflicting parties only, the inclusion of clan elders to witness or use of chiefs to negotiate without him intervening much. Arbitration followed (31.7\%) through chiefs, relevant government officers such as officers from the Ministry of Agriculture and Kenya Forest service staff. Mediation was also used through clan elder engagements facilitating the negotiation process. Litigation was the least preferred $(9.2 \%)$ by seeking legal services in court and was preferred by the well-endowed parties or parties who had no relationship as clan members like neighbours who are new settlers (Table 7).

Table 7: Conflict management process through third party intervention by institutions

\begin{tabular}{ll}
\hline Conflict management process & Percept $(\boldsymbol{\%})$ \\
\hline Arbitration by Government officers and chiefs & 31.7 \\
Avoidance by parties & 4.2 \\
Coercion & 0.8 \\
Litigation (Courts) & 9.2 \\
Mediation (Clan elders) & 10.0 \\
Negotiations (Parties, clan elders) & 44.2 \\
Total & $\mathbf{1 0 0 \%}$ \\
\hline
\end{tabular}

\section{Effectiveness of Cooperative Methods of Conflict Resolution Mechanisms}

Negotiations led to the highest loss of income of KES 177,993 followed by KES 147,907.14 from avoidance mechanisms and mediation the third most costly. Litigation was the least costing method because it is the least preferred conflict management mechanism

Table 8: Average losses incurred by parties for various mechanism of conflict management

\begin{tabular}{ll}
\hline Conflict resolution mechanisms & $\begin{array}{l}\text { Average losses incurred by the aggrieved party (KES) per } \\
\text { conflicts session }\end{array}$ \\
\hline Negotiation & $177,993.00$ \\
Avoidance & $147,907.14$ \\
Mediation & $60,170.00$ \\
Arbitration & $48,462.00$ \\
Coercion & $40,450.00$ \\
Litigation & $15,500.00$ \\
Total & $\mathbf{4 9 0 , 4 8 2 . 1 4}$ \\
\hline
\end{tabular}

\section{DISCUSSIONS}

\section{Understanding Tree-Based Conflicts from Boundary Tree Planting}

In order to understand tree-based conflicts in boundary tree planting, the study focused on the nature of conflicts based on the damage caused by trees due to planting in the boundary, the extent, severity and stage of the conflict, and the actors/land users involved in conflicts. Damage of crop by trees was the most prevalent among respondents $(65.2 \%)$. This is because the trees led to a decline in productivity of crops such as tea and maize by competing for nutrients, allelopathy, and draining water from crop use. The rest of the negative effects caused by trees that lead to conflict include house destruction, land encroachment, health risk when trees are casting shadows of the properties, littering neighbours' compound, 
ownership and causing the death of livestock when harvesting happens. This means conflicts arose between tree growers and crop farmers, tree growers and land or property owners; and tree growers and livestock keepers. Similarly, these conflicts had mainly been expressed through assault as an expression of disagreement between parties, including altercation, followed by those expressed in a mild subtle manner and a few cases of violence. Even though reported violence cases of tree-based conflicts were few, they were severe as they led to the killing of parties and even violence against widows and women. This, therefore, qualifies the tree-based conflicts to be a serious issue that needs urgent interventions. Although mild expression of conflicts was recorded, this may not have been a true reflection since there were several reported cases of conflicts reported at the Kenya Forest service office.

There was also a relationship or association between the tree species planted on the boundary and the nature of conflicts. For instance, Eucalyptus spp. and Grevillea had the highest contribution to all types of conflicts including damage to crops and imposing health risks as opposed to tree species such as Markhamia lutea, Psidium guajava and Croton macrostachyus. The tree species planted on the boundary are contrary to the technical silvicultural recommendations on the appropriate species to be planted on the boundaries (Tengnas, 1994; Dewees, 1995) due to the competitive nature of Eucalyptus such as on-farm. For instance, Eucalyptus guideline by KFS prohibits the planting of Eucalypt within 6 meters from any one's boundary and the distance between the two boundaries not occupied by Eucalyptus should be at least meters apart and that Eucalyptus should not be planted on agricultural lands less than $1 / 4$ of an acre. Even though such restrictions of Eucalyptus planting have been documented officially, they are not strengthened by any legal requirements. Only the Physical Planning Act 2012 provides for a sixmeter setback distance to be left while undertaking development from the road reserve but does not mention anything to do with the tree planting. Due to lack of legal basis for the six meters setback devised by KFS, tree growers defy the requirements of the guideline on Eucalyptus tree planting arguing that it is just a mere policy and no legal standing to force them to adhere to the rule (KFS, 2009). The requirement by the Physical Planning Act (2012) of leaving a setback of six meters from the boundary of one's farm and that Eucalyptus planting on a farm less than $1 / 4$ is not observed (KFS, 2009).

There was also an association between land size with the nature of tree-based conflicts where the small landholdings led to more tree-based conflicts with the highest being those related to use of tree planting as a strategy of land encroachment and small landholdings also being prone more to damage of trees to crop productions. The landholdings ranged from 0.25 acres to 5 acres. Although the land subdivisions were adhered to according to the requirements of the Physical Planning Act on control of land subdivisions, the small landholdings by most respondents led to treebased conflicts because it was impossible for them to adhere to the KFS rule of 6 meters set back between two boundaries.

\section{Conflicts Coping Mechanism}

Cooperative methods of conflict resolution were the most prevalent (58\%). These methods included the felling of trees planted on the boundaries after a talk with the aggrieved party; silvicultural management methods such as the pruning of branches and pollarding of Grevillea; and trench digging by the aggrieved parties to prevent neighbouring trees roots from affecting their crops negatively. Compensation of damage caused by trees on properties and livestock; sharing tree ownership between farmers who plant trees and those who do not plant trees but get affected by neighbouring trees. Even though these methods are viable and some based on technical silvicultural recommendations, they were not employed by tree planters as precautionary measures but rather after having encountered conflicts with the neighbours. Prior consent or agreement with the neighbours in case of small landholding tree planting on the boundaries have been recommended by (Tengnas, 1994). However, in this study, prior agreements were not respected by the parties who got into an agreement on how to avoid boundary tree planting conflicts. The prior consent and legally binding agreement on such coping mechanisms may help to prevent conflict between different land users where there is little option left rather than tree planting in the small landholdings. 
Compensation was also embraced by conflicting parties either through voluntary agreements or through coercion from an arbitrator or the court institutions. Compensation of damage/cost incurred caused by conservation or trees planted on-farm are documented (Redpath et al., 2013) and also provided for in the Farm forestry rules of the agricultural act of Kenya (GoK, 2009a). As long as the procedure of assessments of damage and valuation of the damage is established by the County Agricultural Committee.

The use of non-cooperative/ competing methods is also high among respondents where parties avoid managing conflicts, defy authorities summons to mediate or arbitrate or even ignore any actions recommended. Some also prefer to go to court after longstanding conflicts.

Local methods of voluntary negotiations are preferred by most parties. Especially parties who want to maintain peace with neighbours to whom they have relations with from the clan level. However new settlers tend not to have such local voluntary negotiations but instead settle their issues in court or with government authorities. The constitution of Kenya Chapter Five encourages the communities to settle land disputes through recognized community initiatives consistent with the constitution. The institutions used by the land use parties here take into cognizance but also tend to prefer local institutions including even church institutions and mediation by clan elders. Such institutions with explicit power to solve conflicts include the chief, the ministry of Agriculture officer (GoK 2009a) and the national land commission and land control board. The Authority to help resolve such disputes, however, is not provided for in the Forest Conservation and Management Act yet trees are the main subject in the FCMA 2016. Despite these limitations, most aggrieved parties on boundary tree planting most often report to either Kenya Forest Service or The Ministry of agriculture in case of valuation exercise is required to claim compensation. This limits Kenya Forest Service on their ability to help with resolving such boundary tree planted conflict despite having been receiving so much of the same cases. There is need to have such provisions in the FCMA 2016 or to have multiagency cooperation in conflict management arising from tree planting on the boundaries.

\section{Effectiveness of Conflict Management Mechanisms}

Even though cooperative methods of voluntary negotiations yielded much in reducing the occurrence of conflicts or damages from conflicts and enhancing good relations, it involved compromise or consensus agreement between parties which cost the aggrieved party a lot of income loss. This was through opportunity cost introduced by crop losses from tree damage; the cost used to repair the damage of properties and the cost incurred in trying to find justice. Avoidance equally led to higher loss of income by the aggrieved parties due to the opportunity cost of the forgone benefits of crops lost and cost of repairs. Certain losses were incurred indirectly by the aggrieved parties by being forced to shift change their livelihood strategies from tea farming to Eucalypts tree growing posing a risk in the sustainability of the enterprise since Eucalyptus growing was entirely dependent in the tea industry in the area. Litigation method cost the parties the least. This is contrary to the findings by many that litigations and court cases are usually financially demanding. This can be explained by the fact that very few respondents usually resolved disputes in courts.

\section{CONCLUSION AND POLICY IMPLICATIONS}

Tree crop conflicts and other forms of conflicts were as a result of non- adherence to existing technical silvicultural guidelines on tree planting on farm exemplified by a poor choice of tree species for the various configurations on the farm. In some instances, policies exist but have not been strengthened by legal backing. High economic value for such species as Eucalypts and Grevillea robusta having been perpetuated by the tea industry which is booming in the area makes farmers give a wide berth to technical guidelines on Eucalyptus growing. Improper planning for tree planting where involvement of relevant stakeholders, neighbours and relevant government agencies concerned with tree planting prior to the exercise will help prevent potential tree-based conflicts. Even when consultations are done prior to conflicts arising, they are usually informal and non-binding, which makes it hard for parties to respect them to the end 
Thus, the need to have legally binding agreements on terms of tree planting prior to the exercise after consulting relevant stakeholders. Compensation of the aggrieved parties can be explored after proper valuation is done. There is a need to introduce or research on favourable fast-growing tree species with high economic value and with low competitive interactions with crops. Even though cooperative voluntary negotiations mechanism were highly effective in reducing conflicts and destructions, and promoting peace among parties, they imposed high costs or losses to the aggrieved parties when they have to compromise or seek justice. Therefore, in cases where boundary planting of trees have to be done with less adherence to the existing policies and legal framework due to the small landholdings, prior consultations with relevant neighbours should be done accompanied by binding consent from both parties.

\section{CONFLICT OF INTEREST}

The authors declare that there is no conflict of interests regarding the publication of this paper

\section{ACKNOWLEDGEMENT}

The authors are grateful to Judith Aluoch for her insights on land use planning, other enumerators from Kisii study sites for their assistance in data collection, forester Nyatich, other KFS Kisii staff, and other Kisii local authority members for their courtesy and hospitality as we collected data. Financial support for this study was provided by Kenya Forestry Research Institute, Socioeconomic, policy and Governance Office

\section{REFERENCES}

Boulle, L. (2005). ediation: Principles, process, practice. Chatswood. NSW: Lexis-Nexis Butterworth.

Brahm, E. (2003). Conflict stages. Beyond intractability. Conflict Research Consortium. Boulder: University of Colorado.

Condliffe, P. E. (2002). Conflict Management:a practical guide (2nd ed.).
Sydney,
Australia:
LexisNexis
Butterworths.

Costello, L. R., McPherson, E. G., Burger, D., \& Dodge, L. L. (2000b). Strategies to Reduce Infrastructure Damage by Tree Roots: A Symposium for Researchers and Practitioners. Proceedings of a Symposium. Western Chapter.

Dewees, P. A. (1995). Trees on farms in Malawi: private investment, public policy, and farmer choice. World Development, 23(7), 1085--1102.

Gerber, J. F. (2011). Conflicts over industrial tree plantations in the South: Who, how and why. François, 165-176.

Glasl, F. ". (1982). The process of conflict escalation and roles of third parties." In Conflict management and industrial relations. Springer, Dordrecht, 119-140.

GoK. (2009a). Agriculture (Farm Forestry) Rules. Nairobi: Government printers.

Gombya-Ssembajjwe, W. (1998). Conflicts in community forestry: experiences from Uganda. Integrating Conflict Management Considerations Into National Policy Frameworks: Proceedings of a Satellite Meeting to the XI World Forestry Congress, 10-13 October 1997, (p. 299). Antalya, Turkey: FAO.

Hassall, G. (2005). Alternative dispute resolution in Pacific Island countries. Journal of South Pacific Law, 9(2), 2009.

Joshi, M., \& Palanisami, K. (2011). Impact of eucalyptus plantations on ground water availability in South Karnataka. ICID 21st International Congress on Irrigation and Drainage, (pp. 255-262).

Kazoora, C. (2003). Conflict resolution in the Namanve Peri-Urban Reforestation Project in Uganda. Natural resource conflict 
management case studies: an analysis of power, participation and protected areas, 39. In P. A. Nielsen, Natural resource conflict Management Case studies :An nalysis of Power Participation and Protected areas (pp. 39-58). Rome: Food and Agricultural Organisation.

Kenya Forest Service. (2009). A Guide to OnFarm Eucalyptus Growing in Kenya. Nairobi.

Kisii County Government. (2018-2022). County Integrated Development Plan. Kisii.

Loode, S., Nolan, A., Brown, A., \& Clements, K. (2009). Conflict management processes for land-related conflict. Fiji: Citeseer.

Morton, D. (1973). The resolution of conflict: Constructive and destructive processes. New Haven CT: Yale University Press.

Mugunga, C. P. (2016). The use of Eucalyptus in agroforestry systems of southern Rwanda to integrate or segregate? Wageningen, NL: Wageningen University,.

Nader, L., \& Todd, H. F. (1978). Nader, Laura and Todd, Harry F. The disputing process: Law in ten societies.

Nicoll, B. C., \& Coutts, M. P. (1997). Direct damage by urban tree roots: Paving the way for less damaging. In Arboricultural Practice, Present, and Future, 77-78.

Noll, D. (2000). Conflict dynamics.. . Los Angeles Daily Journal Verdicts and Settlements.

Pendzich, C., Thomas, G., \& Wohlgenant, T. (1994). The role of alternative conflict management in community forestry. Forests, Trees and People Programme. FAO. Rome: FAO.
Pondy, L. R. (1967). Organizational conflict: Concepts and models. Administrative science quarterly, 296-320.

Redpath, S. M., Young, J., Evely, A., Adams, , W. M., Sutherland, W. J., Whitehouse, A., . . Gutierrez, R. J. (2013). Understanding and managing conservation conflicts. Trends in ecology \& evolution, 28(2), 100$-109$.

Reimann, C. (2004). Assessing the state-of-theart in conflict transformation. In A. F. Austin, A. Austin, F. Martina , \& R. Norbert (Eds.), Transforming ethnopolitical conflict (pp. 41--66). Fachmedien Wiesbaden GmbH: Springer.

Sobola , O. O., Amadi, D. C., \& Jamala, G. Y. (2015). The role of agroforestry in environmental sustainability. IOSR Journal of Agriculture and Veterinary Science,(5), 8.

Tengnas, B. (1994). Agroforestry extension manual for Kenya. Nairobi: World Agroforestry Centre.

Tjosvold, D., Wong, A., \& Chen, N. Y.-F. (2014). Cooperative and competitive conflict management in organizations. Handbook of conflict management research, 545-568.

Ury, W. L., Brett, J., \& Goldberg, S. (1993). Getting disputes resolved. Cambridge: PON Books Cambridge, MA. 